\title{
The Impact of the Music Industry in Europe and the Business Models Involved in Its Value Chain
}

\author{
Blanca de-Miguel-Molina (iD), Rafael Boix-Doménech (D), \\ and Pau Rausell-Köster (iD)
}

\section{Introduction}

The impact of creative and cultural industries can be analysed using different values, with the focus depending on the subject. From a cultural point of view, Addis and Rurale (2021) considered four values: the identity value, the economic value, the creative value and the well-being value. Applied to the music industry, the identity value is associated with its ability to create a community and its interest for both current and future generations. The economic value is related to the revenue streams the music industry generates, while the creative value refers to its ability to innovate. The well-being value of the industry is represented by the effect of music on our mental state and how we change the songs we listen to depending on the context. From the economic viewpoint, Oxford Economics, in its report for IFPI (2020b), measured the direct and indirect impact of the industry. According to this report, the industry employed a total of two million people in 2018. Direct impact accounted for 1.3 million employees and indirect impact for 0.7 million people. This chapter aims to focus on the industry's economic and creative value.

It presents the main data related to the importance of the music industry in Europe, including number of firms and employees. The region is a hub in terms of the amount

\footnotetext{
B. de-Miguel-Molina ( $\varangle)$

Department of Business Organisation, Universitat Politècnica de València, Valencia, Spain e-mail: bdemigu@omp.upv.es

R. Boix-Doménech

Departament D’Estructura Econòmica, Universitat de València, Valencia, Spain

e-mail: rafael.boix@uv.es

P. Rausell-Köster

Departament D’Economia Aplicada, Universitat de València, Valencia, Spain

e-mail: pau.rausell@uv.es
} 
of music recorded and publishing activities, and as an innovative centre in the development of music streaming. The music industry involves many different activities in its value chain and there are different players in each of these activities. In this analysis, some of these activities were selected and the business models of companies engaging in these activities are explained. Some of the companies analysed included the Universal Music Group record label and the streaming services Spotify and Deezer. The study presents their business models, including their value proposition, revenue streams and their key resources, such as proprietary technology, which explain how they compete in their markets. We also aim to discuss the challenges posed by the digital impact on exhibition activities, and to do so, we have focused on opera houses in Europe. As cultural institutions, they are examples of the presence of the identity value and are important to transmit intangible cultural heritage. The opera houses included in the analysis are also examples of creative value as they have been able to adapt to changes in their sector.

\section{The Impact of Music in Europe}

This section focuses on the direct impact of the music industry on the European economy. The most recent analysis (IFPI, 2020b) estimated that the industry has a GDP multiplier effect equal to 2.2, which means that every euro in GDP generated by music creates an additional $€ 1.20$ in total GDP. The multiplier effect in recording activities shows a multiplier effect of 2.8. Therefore, every euro in GDP generated by music recording firms creates an additional $€ 1.80$. Moreover, the report estimated that the direct impact of the music industry on employment in Europe is around 1.3 million jobs. In 2019, the industry in Europe grew by $7.2 \%$, led by the United Kingdom, Germany and France (IFPI, 2020a).

OECD data indicated differences between European countries in terms of the impact of recording and publishing activities on employees and enterprises (see Fig. 1). The greatest impact of these activities came from Germany, the United Kingdom, France and Sweden. In the publishing market, IMPF (2020) reported Europe to be the leading region by revenue in this activity $(52.5 \%$ total revenue), followed by North America (25.6\%) and Asia-Pacific (15.1\%). However, these are only some of the music industry's activities. The total impact of the sector according to the European Commission was estimated at around 1,168,000 employees (European Commission, 2020).

The impact of culture can be explained by the budget households allocate to music activities (Eurostat, 2019). Cultural expenses can generate direct and indirect impacts. Directly, European households spend an average of $1.5 \%$ of their budget on music. There are, however, differences in the percentages for recorded music. For example, the figure stands at $3.8 \%$ in the Netherlands and $2.7 \%$ in the United Kingdom.

European citizens participate in cultural activities in which music is the central feature or an important element of the cultural offering, such as concerts and festivals. 


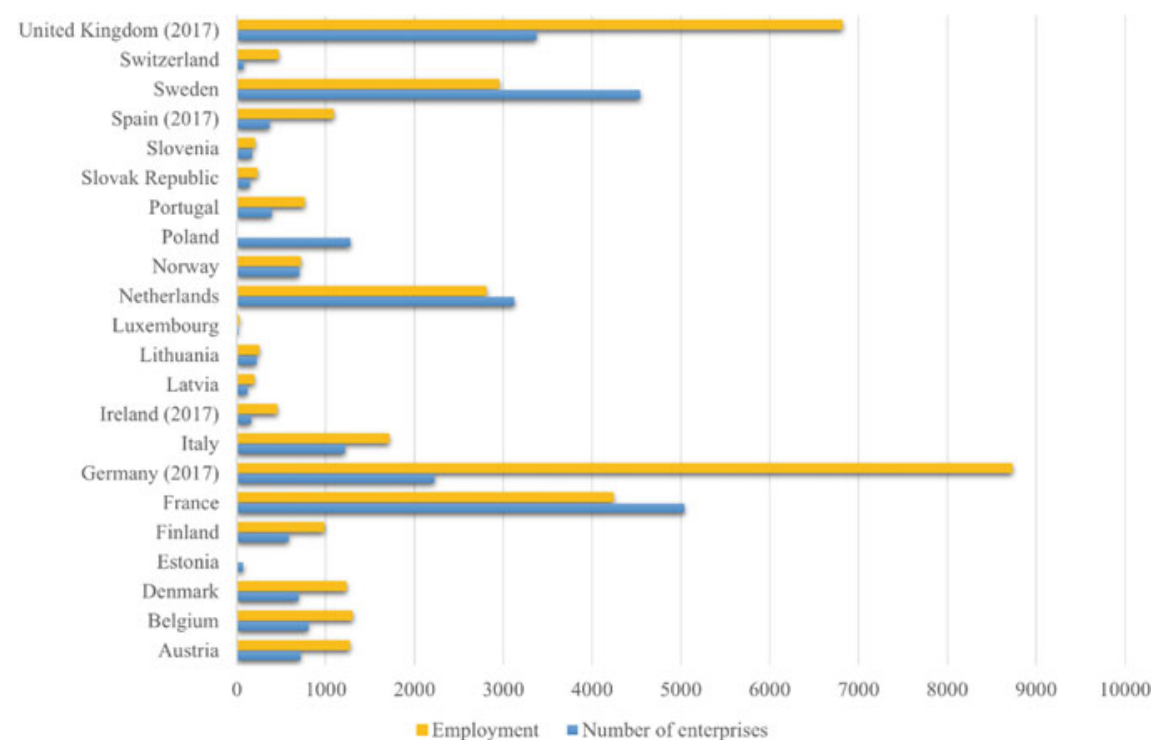

Fig. 1 Impact of sound recording and music publishing activities in Europe in 2018 (Source OECD.Stat)

Eurostat data indicated that $44.5 \%$ of people attended live performances (theatres, concerts and ballet), with the highest percentages coming from Finland $(66.7 \%)$, Norway $(62.5 \%)$ and the Netherlands $(60.5 \%)$. The average price of music festival tickets in Europe from 2014 to 2018 was around $€ 178$ and the audience at a festival like Glastonbury in 2019 was 210,000 people (Statista). This data can explain why total spending on music events organised in arenas in 2018 was around $€ 1,112$ million (IQ Magazine, 2019).

In terms of indirect impacts, households spend around $2.4 \%$ of their budget on musical instruments (Eurostat, 2019). There are also differences between countries with households in Portugal spending around $6.4 \%$ of their budget on these cultural goods, while in Poland this figure rises to $10.9 \%$ of their budget. The impact also differs according to household income with the highest income correlating with the highest budget allocated to culture (Eurostat, 2017).

In the following sections, additional impacts will be analysed through the study of the business models pertaining to specific activities in the music industry.

\section{Business Models in the Music Industry Value Chain}

A business model has been defined as "how companies make money" (Chesbrough \& Rosenbloom, 2002), "how enterprises work" (Magretta, 2002) and "how a firm conducts its business" (Fjeldstad \& Snow, 2018). The use of business models to 
Table 1 Elements of a business model

\begin{tabular}{l|l|l|l|l|l}
\hline \multicolumn{2}{l|}{$\begin{array}{l}\text { Osterwalder and Pigneur } \\
(2010)\end{array}$} & \multicolumn{2}{l|l}{ Fjeldstad and Snow (2018) } & \multicolumn{2}{l}{ Teece (2018) } \\
\hline $\begin{array}{l}\text { Value } \\
\text { creation }\end{array}$ & $\begin{array}{l}\text { Key } \\
\text { resources, } \\
\text { key activities, } \\
\text { Key partners }\end{array}$ & Value creation & $\begin{array}{l}\text { Activities, } \\
\text { resources, } \\
\text { economics }\end{array}$ & Cost model & $\begin{array}{l}\text { Core assets and } \\
\text { capabilities, } \\
\text { core activities, } \\
\text { partner network }\end{array}$ \\
\hline $\begin{array}{l}\text { Value } \\
\text { delivery }\end{array}$ & $\begin{array}{l}\text { Value } \\
\text { proposition, } \\
\text { channels, } \\
\text { customer } \\
\text { relationship }\end{array}$ & $\begin{array}{l}\text { Value } \\
\text { proposition }\end{array}$ & $\begin{array}{l}\text { Product } \\
\text { benefits, } \\
\text { promised } \\
\text { solution } \\
\text { quality, } \\
\text { connectivity } \\
\text { and } \\
\text { conductivity }\end{array}$ & $\begin{array}{l}\text { Value } \\
\text { proposition }\end{array}$ & $\begin{array}{l}\text { Product and } \\
\text { service, } \\
\text { customer needs, } \\
\text { geographies }\end{array}$ \\
\hline Value capture & $\begin{array}{l}\text { Revenue } \\
\text { stream, cost } \\
\text { structure }\end{array}$ & $\begin{array}{l}\text { Value } \\
\text { appropriation }\end{array}$ & $\begin{array}{l}\text { Revenue } \\
\text { mechanisms, } \\
\text { protection } \\
\text { mechanisms }\end{array}$ & $\begin{array}{l}\text { Revenue } \\
\text { model }\end{array}$ & $\begin{array}{l}\text { Pricing logic, } \\
\text { channels, } \\
\text { customer } \\
\text { interaction }\end{array}$ \\
\hline
\end{tabular}

Source Authors' own

explain how businesses compete has grown in recent years. Nowadays, there is knowledge about how business models operate (Casadesus-Masanell \& Ricart, 2011) and the importance of connections between the elements of a business model (Osterwalder et al., 2020). There is also more information about what is needed to ensure the success of a business model, such as platform business models (Cusumano et al., 2019). To apply these concepts and explain company business models, authors in the management field have highlighted certain elements which include how value is created, delivered and captured (Teece, 2018). Table 1 presents these elements, with the value proposition being a crucial element, both in the business model and in terms of competitive strategy. As Michael Porter pointed out (Magretta, 2012), a good strategy starts with a unique value proposition. It indicates the offering of products and services, the customer segments which will be targeted for the offering, the channels through which the offering will meet the customers, and how the firm connects with the customer. This value proposition will determine the resources and activities needed to deliver it to customers but also the partners required to support the activities. The revenue model will be based on the value perceived by customers while profitability will also depend on the costs encountered through the activities performed.

The value chain of an industry describes "vertical stages from raw materials into finished goods, where each stage represents a different industry in which firms compete" (Rothaermel, 2019). The value chain in creative and cultural industries involves the different stages from a creative idea to the final customer, who is the audience of the cultural services (De Voldere et al., 2017). In the music industry, the value chain starts with the artists who create a song and finishes with the end 


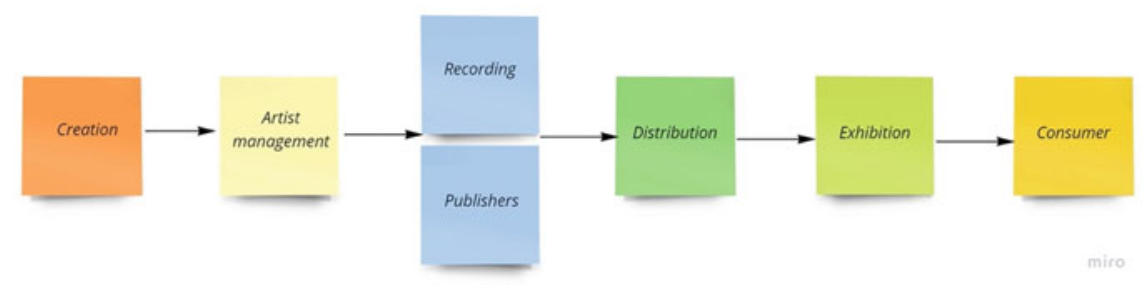

Fig. 2 The music industry value chain (Source Own elaboration from Rausell Köster and Montagut Marqués [2016] and De Voldere et al. [2017])

customers (Fig. 2). Recording activities refer to the sounds in a song while the publishing activity deals with the writing of the song. Therefore, the business model of music publishing firms is based on monetisation of songs, while the core of record labels' business model is monetisation from the song's recording (Simon, 2019). However, some record labels increase their revenue by including publishing. The distribution activity includes a player that has changed how music is listened to by new generations. In the exhibition activity, some organisations have had to deal with but have also taken advantage of digital transformation to reach current and new audiences.

When business models are considered, the value chain is not a linear system but "a system of interconnected activities which involves a firm, its customers, suppliers and partners" (Amit \& Zott, 2021). In the music industry, companies compete with different business models depending on the activities they perform in the value chain. This chapter analyses the business models of organisations in recording, publishing, distribution and exhibition activities to obtain the main elements in their current business models.

\subsection{Business Models in Recording and Publishing Activities}

Revenue from recorded music amounted to $\$ 21.5$ billion in 2019 MIDIA Research (2020), with three labels accounting for around $66 \%$ of worldwide market share (Music \& Copyright, 2020). These labels are Sony Music Entertainment (19.9\%), Universal Music Group (29.8\%) and Warner Music Group (16.5\%). The remaining market share (33.8\%) is divided between a whole host of independent labels, which have increased their presence in recent years (WIN, 2018). According to IFPI (2020b) estimates, there are 7,400 firms in the recording market in the European Union and the United Kingdom. Market concentration of the three big labels differs between European countries. According to data, ${ }^{1}$ in 2017 , the three labels accounted for $85 \%$ of the market in Spain, 77\% in the United Kingdom and 65\% in the Netherlands. Figure 3 shows the market share for the leading recording and publishing companies,

\footnotetext{
${ }^{1}$ Midea and Worldwide Independent Network (obtained at Statista).
} 


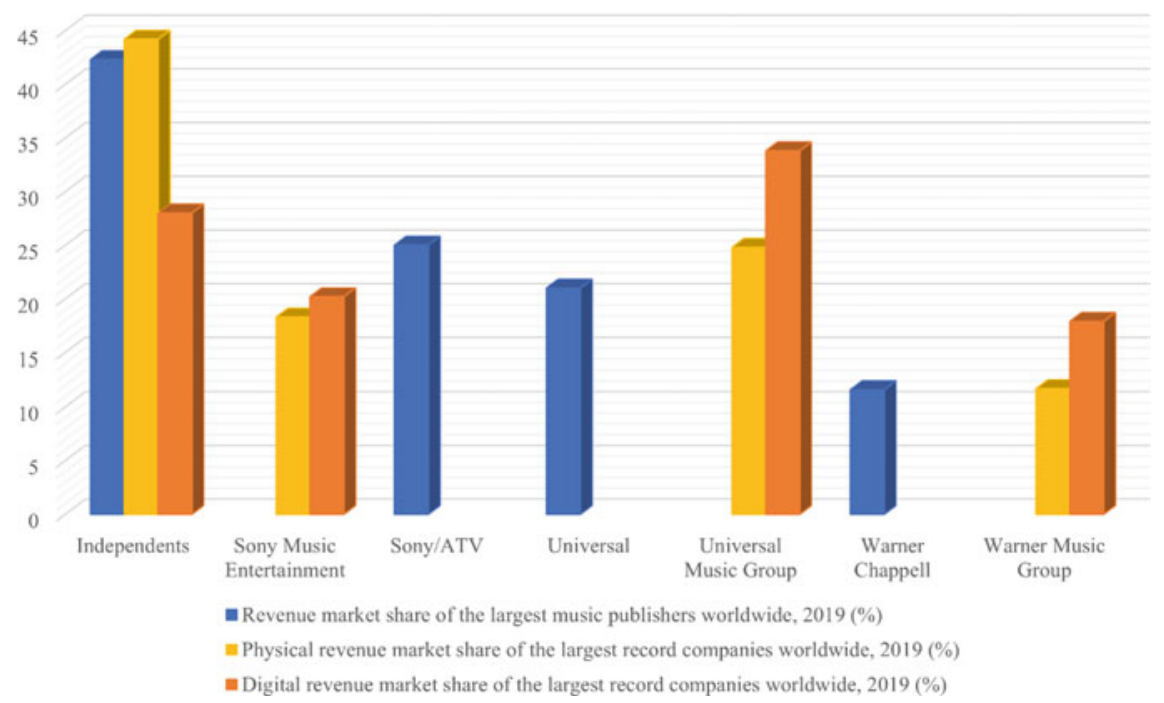

Fig. 3 Market share of music publishers and record companies worldwide, 2019 (Source Statista)

compared to the share of independent companies. The importance of the three largest record labels both in recording and in publishing is clear.

The business models of two European record labels are analysed in this section: the Beggars Group (United Kingdom) and Universal Music Group (Vivendi, France). An analysis of these record labels reveals they own more labels and have acquired even more in recent years. This growth strategy increases the concentration of market share in the hands of big labels as they have more resources to acquire other firms. Moreover, the expansion of labels also involves being a player in the music publishing industry. This strategy enables them to offer services to more artists but also increases the control of assets when negotiating for artists' revenue with other firms. However, revenue from publishing is lower than that obtained through recording, as explained for the two labels under study in the following paragraphs.

The Universal Music Group (UMG) label is owned by the Vivendi corporation and is also the owner of many other firms in the music recording and publishing markets. The label's recorded music revenue stood at $€ 4,252$ million between January and September 2020, with Europe being its second most important market ( $€ 1,231$ million) after North America (2,123 million euros). Its publishing group (UMPG) has recently acquired Bob Dylan's catalogue of songs. ${ }^{2}$ Music publishing generated $€ 876$ million for UMG from January to September $2020,{ }^{3}$ that is, $16.48 \%$ of music revenue. Other revenue streams from the music division are related to physical sales (€604 million, $11.37 \%$ ) and merchandising (€105 million, 1.98\%).

\footnotetext{
${ }^{2} \mathrm{https}: / / \mathrm{www} . u m u s i c p u b . c o m / \mathrm{uk} /$.

${ }^{3} \mathrm{https} / / / \mathrm{www} . v i v e n d i . c o m / \mathrm{en} /$ shareholders-investors/financial-publications-and-reports/financialresults/.
} 
Streaming services, such as Spotify, are an important customer segment for record labels as they pay them for the songs listened to through their platforms. Vivendi indicated in its financial report that UMG's revenue increased during 2020 due to streaming. The label's music revenue amounted to $€ 5,314$ million from January to September, with $€ 2,806$ million coming from subscriptions and streaming $(52.8 \%)$. Therefore, contracts with artists and their catalogue are key assets in their business models given that they offer them to streaming firms as part of their value proposition. Activities are centred on adding value to artists, and especially to those that increase the label's revenue. However, there is criticism over the impact of streaming on the rest of artists for whom revenue from platforms does not guarantee sustainable earnings (Mulligan, 2020b). In terms of the increased control exerted by labels over the music that is available to customers (Kask \& Öberg, 2019), IMPALA, the association of independent music companies, estimated ${ }^{4}$ that the three majors account for around $95 \%$ of the hits, dominating the market. This is because big labels have more people working for artists and make all the departments in the company available to them, including marketing, creative teams, press and publicity (IFPI, 2019).

The Beggars Group is an independent record label which owns ${ }^{5}$ or has a shareholding in various independent labels, such as 4AD, Matador, Rough Trade, XL Recordings and Young Turks. In 2019, its revenue amounted to $£ 37.7$ million, according to the company's annual report. ${ }^{6}$ The turnover analysis indicates that $82.8 \%$ of its revenue was obtained from sales and licensing of sound recordings, with $26.2 \%$ of them obtained in the United Kingdom and $73.8 \%$ in other countries. The Beggars Group also offers music publishing services. However, as an independent label, they do not have the infrastructure of the three big labels, so they need to be more innovative. Data from IMPALA indicates that independent music produces $80 \%$ of new releases. Moreover, the independent firms' strategy centres on specific genres, which might explain the higher percentage of artists that decide to renew their contracts with them (WIN, 2018). In some countries, however, this loyalty is higher, as is the case of Spain (97\%), the Netherlands (93\%) and Denmark (90\%). On the contrary, loyalty is lower in other countries like Germany $(68 \%)$, the United Kingdom (63\%), France (48\%) and Italy (41\%).

In music publishing, firms protect songwriters, whose concern centre on the low rewards they receive from streaming services. According to MMF (2019), it is not a streaming issue but a question of too many participants in the royalty chain, each of them keeping a percentage of the value generated by the songwriter. Figure 2 indicates that big labels are also present in the publishing business, although independent companies are important in both recording and publishing activities. The main sources of revenue for publishing companies (IMPF, 2020) are television and radio $(38.8 \%)$, live and background music (30\%) and digital music (19\%). Examples of independent firms in the publishing market are BMG and Kobalt.

\footnotetext{
${ }^{4}$ https://impalamusic.org/stats-2/.

${ }^{5} \mathrm{https}: / /$ www.beggars.com/group/about.

${ }^{6}$ https://find-and-update.company-information.service.gov.uk/company/01414045/filing-history.
} 
BMG is the music division of the German corporation, Bertelsmann. The division offers artists publishing, recording and audiovisual services and live performances. BMG has extended the services it provides to artists to give them a comprehensive offering. For example, they have included neighbouring rights, and in 2020, they acquired Undercover $\mathrm{GmbH}$, to create a business unit for live music and events. They also included artist management in 2019. Its key resources are its staff (900 employees) and its proprietary technology, developed to improve customer transparency. Moreover, this technology also provides clients with data about the market, which helps them when making decisions. Deals with major artists are also an important key resource for BMG. Revenue from the division in 2019 was $€ 600$ million, $50 \%$ of which came from the United States and 16.6\% from the United Kingdom.

Kobalt Music Group is an independent music firm which offers artists recording, publishing and neighbouring rights. In 2019, the firm's revenue amounted to $\$ 543.4$ million, according to their financial report. This firm has also invested in proprietary technology, increasing transparency for clients and offering them personalised data about the market. According to Kobalt, this helps the firm to attract new clients and retain existing ones. The firm's key resource is its employees (650) and they mention the royalty collection societies as an important partner.

In conclusion, firms in publishing and recording activities base their business models on their clients, who are the artists. They upscale their business models extending the services they offer to each artist, to give them a comprehensive range of options. This also means the firms can grow their revenue streams. In the publishing market, companies have incorporated technology as an element in their value proposition that increases transparency for artists and provides data which is important to evaluate their business.

\subsection{Business Models in Music Distribution}

Streaming services have become an important player in the distribution business. According to data published by Statista (statista.com), worldwide revenue from streaming services amounted to $€ 13,478.8$ million in 2019 . In the first quarter of 2020, streaming services had 400 million subscribers. In Europe, revenue amounted to $€ 4,969.5$ million in 2020 , with 95.56 million users. This means Europe concentrates $36.9 \%$ of revenue and $23.9 \%$ of users. In the European market, there are general streaming platforms such as Spotify (Sweden, Luxembourg), Deezer (France), SoundCloud (Germany) and Tidal (Norway). There are also niche streaming services like Idagio (Germany), which is focused on classical music. The type of business model these platforms use is a freemium model, in which users select between free and premium subscriptions (Simon, 2019). Rivalry in the market is fierce as these platforms compete with the giant tech companies like Amazon, Apple and Google. Figure 4 shows that the impact of these competitors is greater in some countries than others, while in Scandinavia and France, the European streaming services are the most widely used. 


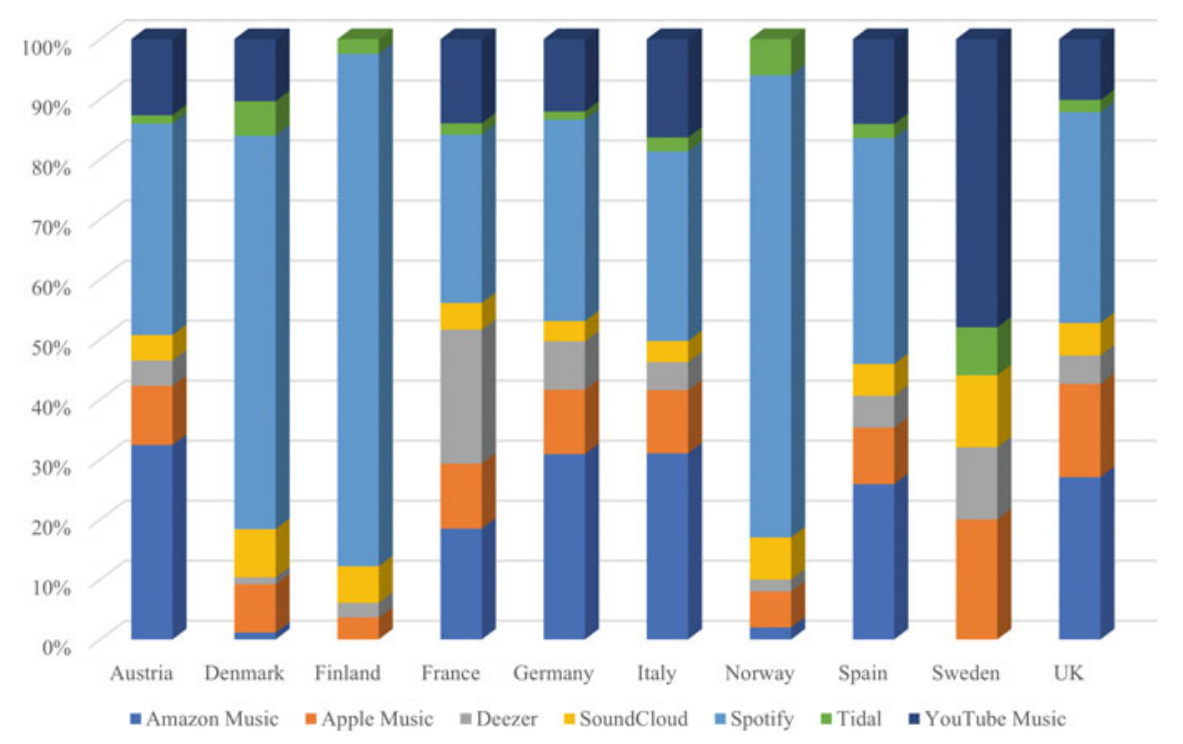

Fig. 4 Percentage of users by streaming service in Europe, 2020 (Source Statista Global Consumer Survey)

Section 3.1 details which streaming platforms are important customers for the record labels and which labels' revenue has increased thanks to these platforms. Streaming services have business models based on a two-sided platform, which require several factors to be and remain successful. Cusumano et al. (2019) cited the network effect, switching costs and multi-homing, the selection of profitable customers, entry barriers and being 'asset-light' as some of the elements included in these business models.

The network effect means that the platform needs users on both sides, i.e., artists and fans. Up until now, it has been easier to connect listeners than to attract artists. This explains why Spotify has created new services in an attempt to attract more artists to its platform. Its most recent strategy to appeal to artists has centred on partnering with a label, in this case, the Universal Music Group, and offering them new services. The results appear to be positive, according to Spotify's financial report. However, support from authors needs to give them a valuable service which can be converted into revenue.

With regard to switching costs and multi-homing, the lower the price of digital platforms, the greater the threat of multi-homing. This means that users are not loyal to one platform and they change from one to another or combine platforms simultaneously. As Vroom and Sastre Boquet (2019) pointed out, labels offer their catalogue to any platform that is interested and this restricts platforms' ability to differentiate their value proposition. Platforms need to offer additional services and improve the user experience to reduce the threat of multi-homing. They also need to try to increase switching costs for users by encouraging them to increase the amount 
of information they self-compile in their accounts, such as their playlists, for example. However, these elements can be easily copied by competitors, implying that platforms need to innovate continuously to offer differentiated services. Moreover, artists also use multi-homing to reach more fans and this increases rivalry between streaming services that try to be different, with the smallest platforms coming off worst. This rivalry increases when television streaming platforms include music-related products in their offering, such as concerts and documentaries.

The selection of profitable customers seems to be a complex task when we look at the platforms' financial results. We used Spotify and Tidal as examples, because they are more transparent with information, especially Spotify, as it makes information available through its website. Spotify's revenue amounted to $€ 5,712$ million from January to September 2020, which is greater than the revenue cited previously for UMG. However, Spotify obtained an operating loss of $€ 224$ million and a net loss of $€ 456$ million in the same period. Table 2 presents the impact of each user segment on the operating loss. Spotify had 144 million (43.8\%) premium users and 185 million (56.2\%) free users supported by advertisements. Therefore, premium users generated $91.9 \%$ of revenue while free users generated only $8.1 \%$ of turnover. As the cost of revenue plus operating costs amounted to $€ 5,936$ million, if costs are divided according to the revenue they generate, premium users would account for $€ 5,455.2$ million (91.9\%) and free users for $€ 480.8$ million. However, if costs are divided by the number of users, the issue generated by free users becomes obvious, as Vroom and Sastre Boquet (2019) indicated. The firm's financial report reveals that free users increased more than premium users between 2019 and 2020, which could intensify the profitability issue. This confirms the advice given by Cusumano et al. (2019) about the importance of selecting profitable customers.

We also found data about the revenue obtained by other European streaming platforms. $^{7}$ In 2019, Deezer's turnover amounted to $€ 331.08$ million; SoundCloud earned \$163.25 million; and Tidal's income was \$109.89 million. Although their revenue is lower than Spotify's, the important factor in a business model is profitability. For example, Deezer had seven million subscribers in January 2019 (statista.com), representing around $\$ 47.3$ dollars per user. Deezer, however, states it has 16 million active users, which would indicate more free users than premium users, and represents income of $€ 20$ per user.

Idagio, the niche classical music streaming service, has started to offer a free service although it offers limited access compared to the total value proposition. This could indicate that they are trying to attract more users, based on the theory that some of them will change to a premium option in future. This free option could also attract advertisement revenue. However, it could mean that they have not been able to expand as fast as they hoped, in line with analysts' studies about the impact of the current crisis on the number of premium subscribers (Mulligan, 2020a).

Another element cited by Cusumano et al. (2019) is entry barriers, which in this industry does not seem to be a major issue as new competitors are constantly entering the market. However, it seems that large amounts of funding are required to attract

\footnotetext{
${ }^{7}$ www.dnb.com.
} 


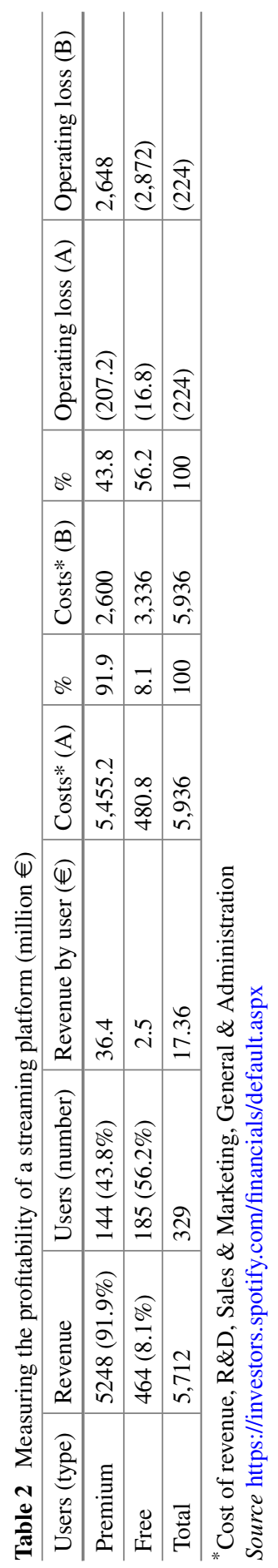


new users. In addition, the cost linked to paying recording and publishing companies is around $70 \%$ of revenue. Tidal offers a breakdown of how each euro from a user's subscription (https://tidal.com/whatistidal) is spent. In a premium subscription, which costs $\$ 9.99$, the company pays $\$ 7.3(73.07 \%)$ to recording and publishing firms for royalties and rights and $\$ 0.40(4 \%)$ to credit card and transaction companies. Tidal keeps $23 \%$ of the user's subscription. The fee for a HiFi subscription is $\$ 19.99$. $71 \%$ of this fee goes to recording and publishing firms, $2.5 \%$ goes to credit card and transaction companies, while Tidal retains $26.5 \%$. Transactions through the App Store increase the user fee by $\$ 3$ to $\$ 6$. Data from Spotify also suggests payments of around $74 \%$. Therefore, platforms need to develop proprietary technology while they design an "asset-light" business model. Technology ensures a premium experience for users and increases the services offered but involves very high investment.

In conclusion, streaming platforms have become an important player in music distribution but rivalry in the market is fierce and guaranteeing the profitability of their business models is a challenge.

\subsection{Business Models in Exhibition Activities}

Here, we analysed the business models of five opera companies located in five European cities: the Royal Opera House (London), La Scala (Milan), the Paris Opera, the Teatro Real (Madrid) and the Vienna State Opera to explain the main elements of each one. They were selected because they are examples of organisations that have managed to innovate while preserving their mission and cultural heritage.

Opera houses are located in historical buildings which have been the centre of social meetings for centuries. The Royal Opera House has been operating out of the Convent Garden theatre since $1858^{8}$; La Scala has been in its building since $1778^{9}$; the Paris Opera ${ }^{10}$ inaugurated the Palais Garnier in 1875 and the Bastille building in 1989; the Teatro Real was founded in $1818^{11}$; and the Vienna Opera House was built in $1869 .{ }^{12}$ Studies indicate that the building, the social interlinks and the quality of performances explain loyalty (Tubillejas-Andrés et al., 2020; Vigolo et al., 2019). Therefore, opera managers consider the atmosphere and the season they offer as important elements of their value proposition, connecting tangible and intangible cultural heritage.

The number of spectators attending opera performances is not high in general. For example, cultural statistics indicate that around $4 \%$ of the population in the United Kingdom and 3.3\% in Spain attended an opera performance in 2019. This percentage

\footnotetext{
${ }^{8}$ https://www.roh.org.uk/about/the-royal-opera/history.

${ }^{9}$ https://www.teatroallascala.org/en/la-scala/theatre/history.html.

${ }^{10} \mathrm{https} / / / \mathrm{www} . o p e r a d e p a r i s . f r / e n / m a g a z i n e / 350$-years/architecture/architecture.

11 https://www.teatroreal.es/en/teatro-real.

12 https://www.wiener-staatsoper.at/en/staatsoper/the-opera-house/history-architecture/\#c4408.
} 
represents 1,306,000 spectators in Spain $^{13}$ and 3,844,789 spectators in Germany. ${ }^{14}$ How much revenue can an opera house obtain solely from attendance? We found data for 2019 about annual revenue for three of the theatres analysed, ${ }^{15}$ but this information did not specify the source of the revenue. The total revenue obtained by the Fondazione Teatro alla Scala di Milano was \$55.99 million; turnover at the Royal Opera House Convent Garden Foundation was \$181.09 million and as the Wiener Staatsoper it stood at $\$ 59.57$ million.

Are there differences in opera productions between European countries? According to the Operabase website (www.operabase.com/statistics), there are differences between opera houses in each country. In the 2019/2020 season, the most popular productions in Italy were Aida (Verdi), Tosca (Puccini) and Carmen (Bizet). In the same season in France, Cosi fan tutte (Mozart), Rigoletto (Verdi) and Madame Butterfly (Puccini) were the most performed works, while in Germany Die Zauberflöte (Mozart) and Don Giovanni (Mozart) headed the list. These differences could indicate that opera houses adapt their season to the audience's preferences but also that they tend to specialise in specific opera productions that can then be offered to other theatres.

It is important to consider that opera houses are based in historical buildings whose upkeep is expensive. They also need to pay employees' salaries, so the greater the number of activities they offer, the larger numbers of people they will need to perform them. To support ${ }^{16}$ its theatres, the Italian government has allocated $€ 182.8$ million to opera foundations for 2021. Opera houses are also supported by firms and associations of opera friends. However, having these historical buildings as a base gives these firms the chance to rent out these spaces and host famous events. This is the case of the Wiener Staatsoper, which hosts the Vienna Opera Ball and the New Year's Concert. The opera orchestra is the Vienna Philharmonic. The Teatro alla Scala Foundation also rents out space in different pavilions to hold events.

The need for revenue streams explains why the value proposition of opera houses includes opera and other performing arts, such as concerts and ballet, thus enabling them to attract different audiences and diversify their revenue stream. Why is ballet a revenue stream for opera houses? It attracts an extra $5 \%$ of spectators to the theatre but more importantly, it appeals to young people. Data for cultural attendance in Finland, for example, reveals that $5 \%$ of people attended classic ballet performances in 2019, while attendance of the 'new generation' (10-14 years old, born after 2000) was $8 \%$. Moreover, attendance of women in this generation was $13 \%$. As theatres need to maintain their intangible heritage (a place where people meet over a period of decades) and transmit it to new generations, offering ballet performances and training is a good strategy. This option can boost opera house sustainability by attracting more community support. The Royal Opera House obtains revenue from activities for children in the mornings, and they also offer education to teachers.

\footnotetext{
${ }^{13}$ Ministerio de Cultura, Spain (Encuesta de Hábitos y prácticas culturales).

${ }^{14}$ German Theatre and Orchestra Association.

15 www.dnb.com.

${ }^{16}$ Ministero dei Beni e delle Attività Culturali e dei Turismo (Italy).
} 
Opera companies and orchestras have been adapting their operations to the digital age as a way to keep their current audience and reach new ones. Kavanagh (2018) explained that some of these organisations have created their own record labels to keep control over this business segment so as not to have to resort to major record labels. The opera houses selected in this chapter offer video streaming of previous operas, concerts, dance performances and other shows. Although some theatres consider this technology as a source of revenue and charge fees to online audiences, others offer free streaming sessions. Opera houses started using social media as a first step in their digital transformation, followed by only selling tickets online. The Wiener Staatsoper also has an online shop focused on opera and it sells records and books. It also offers small screens in the theatre to every spectator so they can follow the subtitles, watch videos and receive other information about the performances. The Royal Opera House also has an online shop to buy other products, apart from tickets.

More recently, the opera houses analysed have introduced video streaming, though with some differences. Streaming became a revenue segment for the Royal Opera House before lockdown (including cinemas) and it kept an online channel open during the mobility restrictions imposed by the pandemic. It has used cinema, television and radio broadcasts to extend audiences in innovative ways. The Paris Opera offers performances through its platform for around $€ 8$. The Teatro Real has its own streaming platform, MyOpera Player, which it also makes available to other opera houses. It offers a yearly subscription model for $€ 90$ or a six-month subscription for $€ 46$. It also offers a non-subscription option, charging about $€ 4$ for each individual show.

In conclusion, opera houses are costly to maintain because they are located in historical buildings and because opera productions are expensive to stage. However, opera house managers and the teams analysed here have innovated to adapt their business models and find new revenue streams while preserving the intangible heritage associated with these institutions. The support of the private sector, governments and communities has helped them to ensure the resources and capabilities required to be able to adapt their business models to digital transformation.

\section{Conclusions}

This chapter has studied the impact of the music industry through the importance of the activities that make up the industry value chain. The business models of certain companies were analysed to obtain the main pointers on how firms compete in every segment of the value chain. The main conclusions can be summarised as follows:

The first conclusion is that the music industry generates a positive direct and indirect economic impact on European countries. The recording industry generates the biggest impact, with a multiplier effect of around $€ 1.80$ euros for every euro spent. Although this impact is greater in some countries, estimates indicate that the sector employs around 1,168,000 workers (European Commission, 2020). 
The second conclusion refers to the business models adopted by recording and publishing firms. Recording is concentrated in a few big labels who rely on streaming services as an important customer segment. Their growth in recent years can be explained by services such as Spotify, which pays them for the songs listened to through its platform. In the publishing market, companies have focused on technologies that increase transparency in their relationships with artists.

The third conclusion is about streaming services, which concentrate around $24 \%$ of users in Europe. Although these services have been described as important customers for recording companies, their dependence on these labels has been pointed out as an important handicap for streaming platforms in terms of profitability. This is a major challenge for streaming services, which have focused more on increasing turnover than establishing profitability through their use of freemium business models.

The last conclusion is centred on the exhibition business through the example of opera houses. These cultural institutions have been able to innovate while preserving their mission and cultural heritage. As attendance at opera performances is not generally high, theatres have extended the number of products and services on offer to capture new revenue streams. These include ballet and training and, more recently, they have also added a digital strategy through streaming services. The difference with other cultural institutions such as museums is that opera houses have considered streaming as a source of revenue.

The music industry comprises many activities and actors that make it difficult to measure their total impact. This chapter has focused on some activities in the industry to indicate how stakeholders' business models influence their ability to generate impact and sustain it over time. A lack of data for some activities makes it difficult to evaluate their total impact, which explains why there are few studies which have attempted to measure their global effect.

\section{References}

Addis, M., \& Rurale, A. (2021). A call to revise cultural business management. In M. Addis \& A. Rurale (Eds.), Managing the cultural business: Avoiding mistakes, finding success (Chap. 1, pp. 1-31). Routledge.

Amit, R., \& Zott, C. (2021). Business model innovation strategy: Transformational concepts and tools for entrepreneurial leaders. Wiley.

Casadesus-Masanell, R., \& Ricart, J. E. (2011). How to design a winning business model. Harvard Business Review, 89(1/2), 100-107.

Chesbrough, H., \& Rosenbloom, R. S. (2002). The role of the business model in capturing value from innovation: Evidence from Xerox Corporation's technology spin-off companies. Industrial and Corporate Change, 11(3), 529-555.

Cusumano, M. A., Gawer, A., \& Yoffie, D. B. (2019). The business of platforms: Strategy in the age of digital competition, innovation and power. Harper Business.

De Voldere, I., Romainville, J. F., Knotter, S., Durinck, E., Engin, E., La Gall, A., Kern, P., Airaghi, E., Pletosu, T., Ranaivoson, H., \& Hoelck, K. (2017). Mapping the creative value chains: A study 
on the economy of culture in the digital age. European Commission. Brussels. https://op.europa. eu/s/owDB. Accessed 14 December 2020.

Eurostat. (2017). Culture statistics-Cultural participation. https://ec.europa.eu/eurostat/statis tics-explained/index.php?title=Culture_statistics_-_cultural_participation\#Cultural_participa tion_by_income.

Eurostat. (2019). Culture statistics, 2019. Publications Office of the European Union.

European Commission. (2020). Creative Europe: Monitoring Report 2019. Publications Office of the European Union.

Fjeldstad, O. D., \& Snow, C. C. (2018). Business models and organization design. Long Range Planning, 51, 32-39.

IFPI. (2019). Global music report 2019. IFPI. https://powering-the-music-ecosystem.ifpi.org/dow nload/GMR_The_Value_of_a_Label.pdf.

IFPI. (2020a). Global music report: The industry in 2019. IFPI. https://www.ifpi.org/wp-content/ uploads/2020/07/Global_Music_Report-the_Industry_in_2019-en.pdf.

IFPI. (2020b). The economic impact of music in Europe. Oxford Economics. https://www.ifpi.org/ wp-content/uploads/2020/12/IFPI_music_in_Europe.pdf.

IMPF. (2020). Independent music publishing global market view 2020. http://www.impforum.org/ impf-launches-independent-music-publishing-global-market-view-2020/.

IQ Magazine. (2019). European arena yearbook 2019. https://www.statista.com/statistics/783308/ live-events-spend-by-genre-in-europe/.

Kask, J., \& Öberg, C. (2019). Why "majors" surge in the post-disruptive recording industry. European Journal of Marketing, 53(3), 442-462.

Kavanagh, B. (2018). Reimagining classical music performing organisations for the digital age. In C. Dromey \& J. Haferkorn (Eds.), The classical music industry (Chap. 9). Routledge.

Magretta, J. (2002). Why business models matter. Harvard Business Review, 80(5), 86-92.

Magretta, J. (2012). Understanding Michael Porter: The essential guide to competition and strategy. Harvard Business Review Press.

MIDIA Research. (2020, March 5). Recorded music revenues hit $\$ 21.5$ billion in 2019. MIDIA Research. https://www.midiaresearch.com/blog/recorded-music-revenues-hit-215billion-in-2019.

MMF. (2019). The songs royalties guide. https://themmf.net/site/wp-content/uploads/2019/05/ mmf_songroyaltiesguide-1.pdf.

Mulligan, M. (2020a, June 3). The global music industry will decline in 2020. MIDIA Research. https://www.midiaresearch.com/blog/the-global-music-industry-will-decline-in-2020.

Mulligan, M. (2020b, November 27). Time to move beyond the song economy. MIDIA Research. https://www.midiaresearch.com/blog/time-to-move-beyond-the-song-economy.

Music \& Copyright. (2020). Total recorded music market share worldwide in 2019, by label. https:// www.statista.com/statistics/947107/recorded-music-market-worldwide-label/.

Osterwalder, A., \& Pigneur, Y. (2010). Business model generation. Wiley.

Osterwalder, A., Pigneur, Y., Smith, A., \& Etiemble, F. (2020). The invincible company. Wiley.

Rausell Köster, P., \& Montagut Marqués, J. (2016). El valor del patrimonio musical valenciano. Una aproximación desde la economía de la cultura. In R. Marzal Raga (Coord.), El valor cultural de la música. Punto de partida para el estudio del patrimonio música (Chap. 14, pp. 183-192). Editorial Aranzadi.

Rothaermel, F. T. (2019). Strategic management (4th ed.). McGraw-Hill Education.

Simon, J. P. (2019). New players in the music industry: Lifeboats or killer whales? The role of streaming platforms. Digital Policy, Regulation and Governance, 21(6), 525-549.

Teece, D. J. (2018). Business models and dynamic capabilities. Long Range Planning, 51, 40-49.

Tubillejas-Andrés, B., Crevera-Taulet, A., \& Calderon Garcia, H. (2020). Assessing formative Artscape to predict opera attendees' loyalty. European Business Review. https://doi.org/10.1108/ EBR-10-2019-0273 (in press).

Vigolo, V., Bonfanti, A., \& Brunetti, F. (2019). The effect of performance quality and customer education on attitudinal loyalty: A cross-country study of opera festival attendees. Nonprofit and Voluntary Sector Quarterly, 48(6), 1272-1295.

Vroom, G., \& Sastre Boquet, I. (2019). Spotify: Face the music. IESE Case. IESE Publishing. 
WIN. (2018). WINTEL Worldwide independent market report 2018. https://winformusic.org/win tel/.

Open Access This chapter is licensed under the terms of the Creative Commons Attribution 4.0 International License (http://creativecommons.org/licenses/by/4.0/), which permits use, sharing, adaptation, distribution and reproduction in any medium or format, as long as you give appropriate credit to the original author(s) and the source, provide a link to the Creative Commons license and indicate if changes were made.

The images or other third party material in this chapter are included in the chapter's Creative Commons license, unless indicated otherwise in a credit line to the material. If material is not included in the chapter's Creative Commons license and your intended use is not permitted by statutory regulation or exceeds the permitted use, you will need to obtain permission directly from the copyright holder.

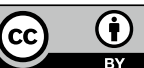

